\title{
Understanding the Need of Implementation of Lean Techniques in Manufacturing Industries: A Review
}

\author{
G. K. Kiran Kumar
}

Department of Mechanical Engineering, Siddartha Institute of Science and Technology, Puttur, Karnataka, India

How to cite this paper: G. K. Kiran Kumar "Understanding the Need of Implementation of Lean Techniques in Manufacturing Industries: A Review " Published in International Journal of Trend in Scientific Research and Development (ijtsrd), ISSN: 24566470, Volume-3 | Issue-3, April 2019, pp.1083-1087, URL: https://www.ijtsrd.c om/papers/ijtsrd23 194.pdf

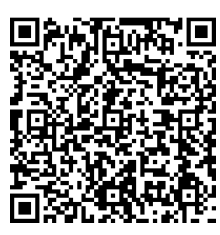

IJTSRD23194
Copyright (C) 2019 by author(s) and International Journal of Trend in Scientific Research and Development Journal. This is an Open Access article distributed under the terms of the Creative Commons Attribution License (CC BY 4.0) (http://creativecommons.org/licenses/ by/4.0)

\section{ABSTRACT}

In competitive environment lean manufacturing is necessary in every industry. Lean production is a standard manufacturing mode of the 21 st century All the manufacturing industries have put a continuous efforts for its survival in these current world. In order to handle the critical situations manufacturers are trying to implement new and innovative techniques in their manufacturing process. Later on lean was formulated and developed as the solution to the fluctuating and competitive business environment. Due to rapid change in business environment the manufacturing organization are forced to face challenges and complexities in the competition. The concept of lean manufacturing was developed for maximize the resource utilization and minimize the wastes. The main focus of the lean manufacturing is to satisfy customer demands for high quality and low cost. The technique not only identifies the reasons for waste but also helps in its removal through marked principles and guidelines. Lean Manufacturing is an efficient and fast growing approach in the world of competition. Lean manufacturing utilizes a wide range of tools and techniques; the choice of tools is based on the requirement. Many parameters contribute success of lean. Organizations which implemented lean manufacturing have higher level of flexibility and competitiveness. However, lean manufacturing provides an environment that is highly conducive to waste minimization. The majority of the study focuses on single aspect of lean element, only very few focuses on more than one aspect of lean elements, but for the successful implementation of lean the organization had to focuses on all the aspects such as Value Stream Mapping (VSM), Cellular Manufacturing (CM), U-line system, Line Balancing, Inventory control, Single Minute Exchange of Dies (SMED), Pull System, Kanban, Production Leveling etc.,

KEYWORDS: 5 S, Waste, Lean Manufacturing, Kanban, Line Balancing

\section{INTRODUCTION}

In the current era of globalization, industries are adopting new tools and techniques to produce goods to compete and survive in the market. The most daunting issue faced by manufacturers today is how to deliver their products or materials quickly at low cost and good quality. One promising method for addressing this issue is the application of lean management principles and techniques. The concept of lean manufacturing was introduced in Japan, and the Toyota production system was the first to use lean practices. Lean manufacturing helps in enhancing production processes and boosting up the employees job satisfaction (Singh Garg, Sharma, \& Grewal, 2010c). Lean manufacturing is different from traditional manufacturing. Lean manufacturing is an important tool used across the industries in the recent scenario. At present the industries are facing a higher level of competition because of the globalization.

\section{LITERATURE REVIEW}

1]. Boppan V. chaudhary (2012), implement the lean manufacturing in a pharmaceutical company, in this paper take a case study of the product line is creams and ointment. Also in industry problem was fixed operating cost and inability to supply products. In this paper improve the operation with help of lean manufacturing so detect the problem where is the waste are occurs, and use the lean tools is VSM. VSM is a mapping method, with the help of detecting value added and non value added process. Prepare a current state map and use the 5-why method for the collect information. And after create future state map for the improvement with the help of 5s tool. and also used cellular manufacturing and after get the result is reduce inventory, and customer satisfaction, and on time delivery, total cycle time reduced, non value added time has been decrease. And reduced the floor space area.

[2]. Jennies angelis (2012) Lean is a globally competitive standard for product assembly of discreet parts. Successful Lean application is conditioned by an 
evolutionary problem-solving ability of the rank and file. This is in itself contingent on employee involvement in improvement programs and the implementation of appropriate practices

[3]. Azharul Karim ( 2013) conducted a research to develop an effective methodology for implementing lean manufacturing strategies and a leanness, following are the methodology are adopted for the present study they are Production and process details, Lean team study, Performance variables. VSM and MTM together and offered a new approach to reduce lead time and to measure productivity based on Lean principle and standardized processes.

[4]. George L. Hodge (2011) conducted a research to identify lean tool for textile industries to eliminate waste and non-value added activities in US to enhance the customer satisfaction, Author identified the following barriers for implementing lean manufacturing they are resistance to change both shop floor employees and management; shop floor employees are reluctant to offer suggestions for improvements; disconnect among marketing, sales, product and development; shop floor personnel are not native English speakers; so training needs to be multilingual.

[5]. Rachna shah 2007 Lean manufacturing is an integrated socio technical system whose main objective is to eliminate waste by concurrently reducing and minimizing supplier, customer, and internal variability.
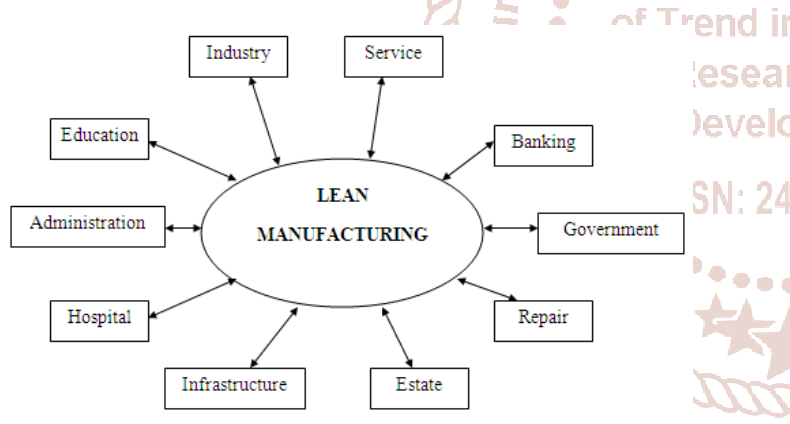

Fig.1.Different work places where lean manufacturing can be used

\section{METHODOLOGY FOLLOWED}

The Main aim of the present study is to find out the needs and examine the degree to which the concepts of lean management are put into practice within various manufacturing Industry.

$>$ Develop a lean manufacturing enterprise

$>$ Understand lean manufacturing principles and its benefits

$>$ It is a measure to identify the constrains that retains lean manufacturing in the infant stage in manufacturing firms and helps to identify the waste that evolves in an processing unit and gives out supporting measures to remove the same. The constraint that predict the implementation and sustainability of lean manufacturing tools and techniques are also discussed.

$>$ This is an overview for finding the current situation of lean management practices in manufacturing industries.

$>$ Apply lean in a production and safe environment

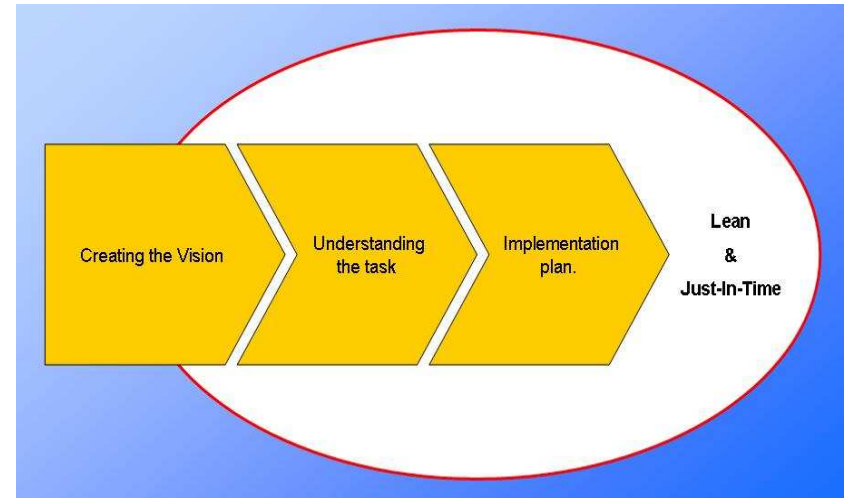

Fig.2.Methodology of lean manufacturing technique

\section{FOUR PILLARS OF LEAN MANUFACTURING}

$>$ JIT(Just In Time)

$>$ Supply chain Integration

$>$ Cellular manufacturing

$>$ Kaizen

\section{Just in Time(JIT)}

The just-In-Time concept requires the raw material for the shop floor at the exact time and not earlier. This leads to a huge fall in the inventory cost. The goal of JIT is achieved by implementing the techniques like.

> Total Productive Maintenance(TPM)

$>$ Standardization

$>$ Kanban

\section{Supply Chain Integration}

The lean system can be effective only if it is executed all along the production chain, i.e., from the suppliers to the customer's customers. Every link along this chain is affected if a single member does not deliver. This is a longt process involving several interfaces. So manufacturers have to take steps towards organizing the supplier base

\section{Cellular Technology}

In traditional manufacturing system the shop floor layout is designed according to the activities. In lean manufacturing it is based on the parts of the product in separate fixed areas. So the layout creates a single peace floor and reduces the order floor time, work in progress, material handling costs and so on.

\section{Kaizen}

Kaizen (pronounced ki-zen) is the Japanese word for continuous improvement. As we use the term, it is a method that strives toward perfection by eliminating waste. It eliminates waste by empowering people with tools and a methodology for uncovering improvement opportunities and making change. Kaizen understands waste to be any activity that is not value-adding from the perspective of the customer. By value-adding, we mean any work done right the first time that materially changes a product or service in ways for which a wellinformed and reasonable customer is willing to pay. Waste consumes resources-both human and material-pointlessly. People implementing wasteful processes are themselves wasted. They are robbed of the satisfaction of engaging in meaningful tasks that produce outputs customers value. Moreover, they are degraded as humans because engaging in activities that are not meaningful treats their energies and earnest 
efforts as commodities of little value. When constrained to execute these imperfect processes without the opportunity to make them better, people are denied the exercise of their capacity to learn and improve and thereby grow to the full measure of their capabilities. As for material resources, the financial and material investments in enterprise are prevented from achieving the greatest returns possible.

\section{BARRIERS USED IN LEAN MANUFACTURING}

$>$ The concept of lean manufacturing might look easy but its implementation is not an easy task.

$>$ The introduction of lean manufacturing into an organization tends to change its working culture. Such changes are considered to be barriers to the implementation process of lean manufacturing.

$>$ Changes occurring in the organization tend to change the workers in the organization.

$>$ Much hard work has to be done to recognize these changes in the organization (Barker,1998; Stanleigh, 2008). Responding and adapting become difficult when a worker sees a change in the environment of the organization.

$>$ This barrier can be overcome by adopting a culture of proper communication and training for everyone in the organization.

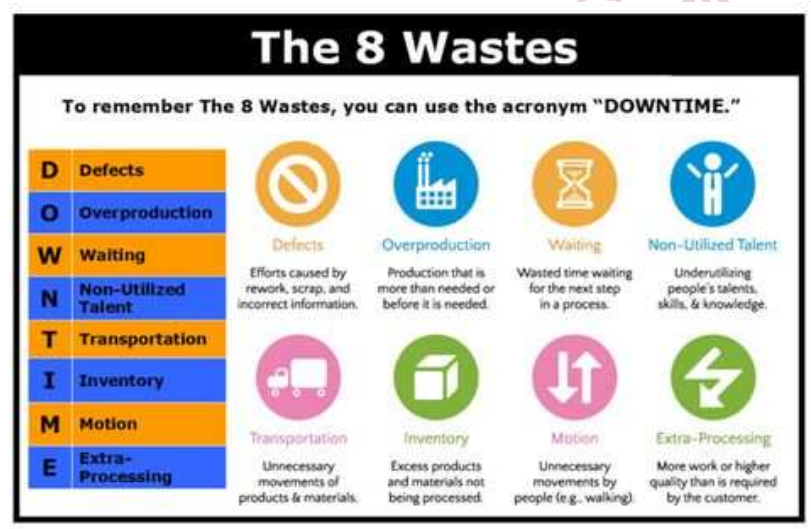

Fig.3.Types of Wastes

\section{METHODS OF LEAN MANUFACTURING}

Method for lean manufacturing is implementation in industry consider some steps are to be taken as following.

1. Select the target or product.

2. Gemba walk, for the collecting data and all the data from product line and industry

3. Prepare a chart or map for the analyzing data and take decision where is the maximum waste or non value added flow, with the help measuring lead time, cycle time, number of workers, and inventory, we are also used the current state map method from VSM.

4. And after completely understand about the waste or non value added, so that decide the lean tools which lean tools apply and give maximum result, Depend on the waste. like tools are 5s- for the decrease the waiting time, cellular manufacturing focus on industry, SMED- reduce the time consuming by change over time and setup. JIDOKAset of practice, mistake proofing and automation, kaizen for continuous improvement.
5. And last one step is improving the problem and gives continuous improvement in future for industry and get increase profit of the industry

\section{TOOLS USED IN LEAN MANUFACTURING}

There are various type of lean tools are available and use this tools and principal, like cellular manufacturing, JIT, continuous improvement, production smoothing, standardization of work, total productive maintenance(TPM), SMED, etc.. We are understood about lean tool one by one in shortly

\section{$>$ Cellular manufacturing:}

Cellular manufacturing reduce the transportation waste. And reduce the inventory. Cellular manufacturing also says "one piece flow" process. It is difficult to fulfill the customer requirement with traditional product line, so using the U- shape product line replace traditional product line.

\section{$>$ Just in time (JIT):}

Just in time is a heart of the lean manufacturing. It's associated with lean techniques. Just in time production gives right part at the right place at right time.

\section{$>$ Scheduling :}

By defining a clear production plan any organization can start initializing the manufacturing system implementation. The production plan generated by scheduling decides service order, allocation of resources and manages queue of service request. This review does not focus the scheduling due to readily available scheduling software's.

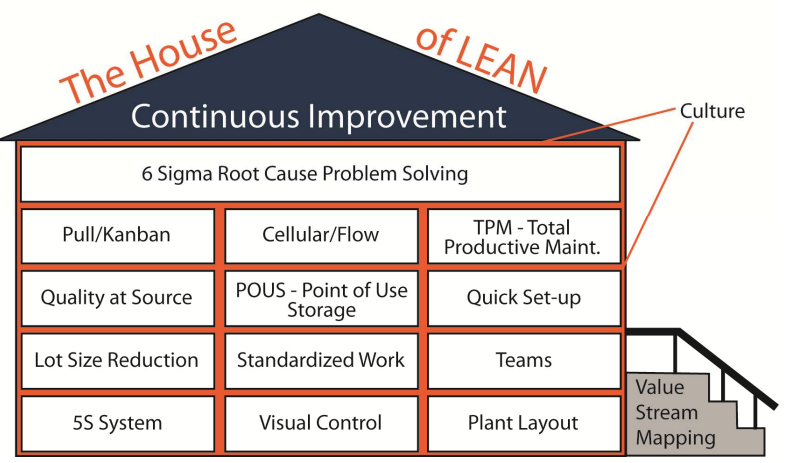

Fig.4.House of Lean Manufacturing

\section{$>$ Kanban System:}

Kanban system, Production smoothing, and setup time reduction are component of any JIT system. "kanban" is a Japanies word which means card or signal. Which process is running and give the basic information about manufacturing

$>$ There are two types of kanban.

1. Single Card Kanban System and

2. Double Card Kanban System

\section{$>$ Single Card Kanban System:}

In a single card kanban system parts are produced and brought according to a daily schedule and deliveries to the user are controlled by c- kanban. 
$>$ Double card kanban system:

1) C- kanban and

2) P-kanban.

\section{C- kanban: Gives signal for deliver more parts to the next process. \\ P- kanban: Gives the signal for require more parts.}

\section{$>$ Waste elimination :}

A target of lean manufacturing is the total elimination of waste. From a customer's point of view, anything that does not add any value to the final product is termed a waste. These wastes can be identified and reduced/eliminated by using lean tools and methods. Upadhye (2010) have successfully implemented the lean philosophy in a north Indian company. In its earlier stages, the lean manufacturing approach was have been found successful in finding and eliminating wastes in medium-sized industries.

\section{Production Smoothing:}

Production smoothing is the process of the balance the work load over different time period. It provide flexibility to respond rush order it is help to eliminate over production.

\section{$>$ Total productive maintenance (TPM):}

Total productive maintenance is the techniques for reducing the machine down time and eliminates the defect and scrap. TPM is a fundamental pillar of lean. It is introducing awareness of self maintenance and also introducing the preventive maintenance of machine.

\section{$>$ Bottleneck process :}

Bottleneck process/constrain in the line is identified by determining the maximum cycle time in the line. The line/ plant capacity is decided by this bottleneck cycle time. Line Capacity is the product of Bottleneck Cycle time $(\mathrm{C} / \mathrm{T})$ and Total Available time, If Bottleneck $\mathrm{C} / \mathrm{T}$ $<$ Takt time, then Customer demand met, If Bottleneck $\mathrm{C} / \mathrm{T}>$ Takt time, and then Customer demand is not met. With the past projected production delivery or from the expected future demand, the takt time is identified for the manufacturing system. With the known Takt time the bottleneck process are identified from the Value stream mapping (VSM), the gap between the capacity and demand is calculated and based on this gap the lean implementation plan is executed.

\section{$>$ Group Technology :}

The successful implementation of flexible manufacturing system need grouping of parts using similarity among the design and manufacturing attribute which make the production plan and manufacturing process flexible. Based on the grouping of parts through similar process, dissimilar machines are grouped together to form a cell concept as suggest by lean concept. Cell formation is purely based on the nature of the process which varies from organization to organization.

\section{Takt time :}

Takt time refers to the frequency of a part or component must be produced to meet customers' demand. Takt time depends on monthly production demand, if the demand increases the Takt time decreases, if the demand decreases the Takt time increases which mean the output interval increases or decreases. The importance of measuring Takt time due to the costs and inefficiency factors in producing ahead of demand, which includes Storage and retrieval of finished goods, Premature purchasing of raw materials, Premature spending on wages, the cost of missed opportunities to produce other goods, Capital costs for excess capacity.

\section{Continuous Improvement:}

Continuous improvement such as improve the quality of product and customer satisfaction. Kaizen and 5s are the component of continuous improvement.

\section{Kaizen:}

Kaizen is a Japanese word kai means continuous and zen means improvement, so its English translation is continuous improvement. Its main focus on completely improve the product and satisfy the customer.

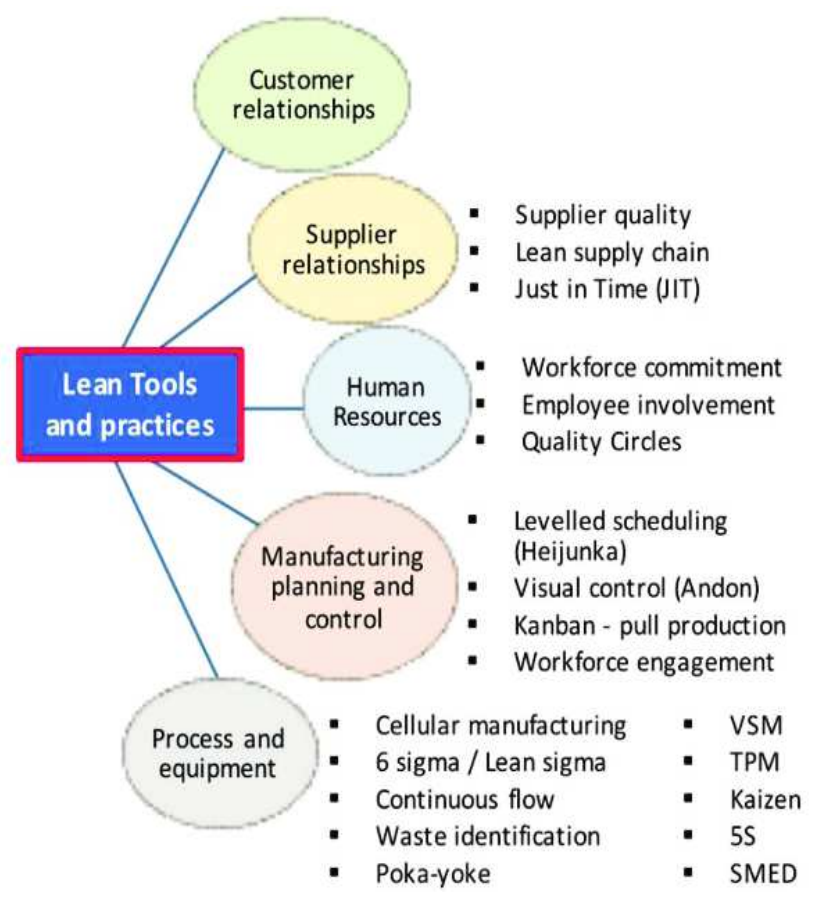

Fig.5.Lean Tools

\section{Line balancing :}

The consideration of task time variability is due to human factors or various disruptions which leads to Uline balancing problem. The task time variability is mainly due to the instability of humans with respect to work rate, skill and motivation as well as the failure sensitivity of complex processes. The task itself a sources of variability and explains the worker performing the task, and the environment where the task is performed. These sources of variability are controlled by minimizing the moving cost of men and machine. The operator walking time and fluctuation of man and machine cycle time leads to line imbalance. Also the change over time creates imbalance in the line for mixed model line which is necessary for lean. Based on demand, the number of worker and machine within the workstation are increased or decreased in order to overcome the line imbalance. Man-machine flexibility is achieved through free flow of material and information in the manufacturing process. 


\section{$>$ Flow Manufacturing :}

The principle of flow manufacturing is producing an item at a time at a rate equal to the cycle time, the successful implementation of flow manufacturing needs U-line layout, multi-skill operator, standardized cycle time, designing operator work as standing and walking manner and the equipment/machine should be standard and less expensive user friendly. The breakthrough or tedious process flow can be balanced by introducing the customized machine in the workstation in order to balance the machine with the workstation cycle time.The mixed model flow is smoothened by designing the workstation with Quick changeover and Small lot size.

\section{$>5 s:$}

It has a five stage of the improvement of the process. It has five " $\mathrm{S}$ " all "S" gives the different meaning and activity. Seiri, Seiton, Seiso, Seiketsu, and Shitsuke. Is a Japanese word and translate into English These 5S is: Sort, Set (in place), Shine, Standardize, and Sustain.

TABLE 1 About 5 ' $S$ '

\begin{tabular}{|c|c|c|c|}
\hline FIRST 'S' & Seiry & Sort & $\begin{array}{c}\text { Sorting out of } \\
\text { the necessary } \\
\text { parts }\end{array}$ \\
\hline $\begin{array}{c}\text { SECOND } \\
\text { 'S' }\end{array}$ & Seiton & Set & $\begin{array}{c}\text { All the parts } \\
\text { arrange of its } \\
\text { proper place. }\end{array}$ \\
\hline THIRD 'S' & Seiso & Shine & $\begin{array}{c}\text { All working area } \\
\text { keep clean }\end{array}$ \\
\hline $\begin{array}{c}\text { FOURTH } \\
\text { 'S' }\end{array}$ & Seiketsu & Standardize & $\begin{array}{r}\text { It is standardize } \\
\text { clean up }\end{array}$ \\
\hline FIFTH 'S' & Shitsuku & Sustain & Keep discipline \\
\hline
\end{tabular}

\section{$>$ Employee perceptions :}

Survey on Employee Perception helps to identify the influencing factors on employees' perceptions for successful lean transitions. The organization must understand the new shop floor work environment and analyze the cultural change of workers' in everyday lives. The detailed study and survey helps to determine which factors make workers feel that lean transformation was successful in order to reveal the building blocks of successful lean transformations. The conclusion of this surveys stratify the perception factor into critical intrinsic factors (commitment, belief) and external factors (lean work method, communication) which affect the success of the lean implementation from workers' point of view and suggest that the possibility of the lean transformation success, is on the hands of employees' commitment levels beliefs, communication and work methods. The belief is an opinion or a conviction about the truth of something that may not be readily obvious or subject to systematic verification. Employee perceptions can be influenced by Belief, Commitment, Work method and Communication. Work methods can strengthen worker identification and involvement, particularly commitment. The employee perception can be achieved through training and awareness by defining road map, metrics and measurement

\section{ADVANTAGES OF LEAN MANUFACTURING}

$>$ The inventory levels can be brought down to nearly nil, thus reducing costs.
$>$ Transitions between various designs take only a few minutes.

$>$ This enables an increased flexibility and better response to customer requirements.

\section{CONCLUSION}

The Conclusion of this review paper reveals that the successful Lean Manufacturing System implementation needs the planning, commitment, learning, safety , integration, Proper Methodology and meanwhile simultaneous implementation of Lean elements along with proper sequence. Manufacturers are under intense, remorseless pressure to find a new ways to reduce production cost, elimination of waste, enhance high quality of product, increase the productivity, and better customer satisfaction. These parameters are usually achieved through the implementation of lean management practices in their industries. Now every industry has to shed conservative attitudes and reform their working practices with lean tools. The attitudes of the work-force in industry also require much cultural change in order to save their livelihoods. This review paper helps to industries and researchers to know and learn about Lean Managements Tools, and techniques, so it could be a very support to opt suitable and proper lean model for implementation, continuous development and for sustaining in the present competitive business environment.

\section{REFERENCES}

[1] Richard Schonberger. Best Practices in lean six sigma process improvement. John wiley \& sons,Inc; 2007.

[2] Wilson, L. How to Implement Lean Manufacturing. New York: McGraw-Hill Professional Publishing; 2009.

[3] Petersen, J. Toyota Way. Blacklick, OH, USA: McGraw-Hill Professional Publishing; p.28-33. 2003.

[4] Womack, J.P., Jones, D.T. and Ross, D. The Machine That Changed the World. Canada: Macmillan Publishing Company; 1990.

[5] Liker, J. Toyota Way. Blacklick, OH, USA: McGrawHill Professional Publishing, p. 28-33,2003.

[6] Monden Y, Toyota Production System. Industrial Engineering and Management Press, Norcross, GA 1983

[7] David Magee, How Toyota Became \# 1 Leadership Lessons from the World's Greatest Car Company. New York, USA: Penguin Group. 67. 2007.

[8] Selection and peer-review under responsibility of Institute of Technology, Nirma University, Ahmedabad.

[9] Journal of Manufacturing Technology Management, 17,56-72.Shingo, A Revolution in Manufacturing: The SMED System, Productivity Press, Portland, 1985.

[10] Liker, J.K, The Toyota Way, McGraw-Hill, New York, 2004. 